\title{
The Comparison of Milking Hygiene with Bulk Tank Somatic Cell Count and Total Bacterial Count in Dairy Herds in Tekirdag Province
}

\author{
Sila TOSUN ${ }^{1}$, Duygu BAKI ACAR ${ }^{*}$ \\ 'Afyon Kocatepe University, Faculty of Veterinary Medicine, Department of Obstetrics and Gynaecology, 03200, Afyonkarabisar, Turkey
}

\begin{abstract}
The investigation of mammary health and milking hygiene procedures, bulk tank milk somatic cell count (SCC) and total bacterial counts, and detecting deficiencies and mistakes following the comparisons of results in Tekirdag province were aimed. The bulk tank milk samples were collected from 50 family farms. $150 \mathrm{~mL}$ of sterile milk samples were taken from milk tanks. Somatic cell counts and total viable bacterial counts were analyzed. On the milk sampling day, a questionnaire was filled out to farm personal or owner to evaluate mastitis control programs applied in the farms. In the bulk tank milk samples, mean SCC was found 560204.08 $( \pm 12399.769) \mathrm{cells} / \mathrm{mL}$, and mean total viable bacterial count were found $1,796,718.36( \pm 156,573.31) \mathrm{CFU} / \mathrm{mL}$. After survey and laboratory analyzes, it was detected that premilking cleaning and drying, teat-dipping, strip before milking, dry-cow management and mastitis control program procedures were using hardly ever. In conclusion, SCC and total bacterial count were higher than acceptable values due to the insufficient practice of mastitis control programs in the small and middle family farms in Tekirdag province. It was considered that some education seminars and/or contact meetings about this issue should be planned to increase mammary health status and milk quality.
\end{abstract}

Keywords: Cow, bulk tank milk, somatic cell count, total bacterial count, mastitis control programs

\author{
$* * *$ \\ Tekirdağ İlinde Bulunan Süt Sığırcılığı İşletmelerinde Sağım Hijyeni Uygulamaları ile Tank Sütü \\ Somatik Hücre ve Toplam Bakteri Sayılarının Karşılaştırılması
}

ÖZ

Sunulan çalışma ile Tekirdağ ilindeki aile tipi süt işletmelerinde meme sağlığı ve sağım hijyeni uygulamalarının incelenmesi, işletmelerden alınan tank sütü örneklerinde somatik hücre sayısı (SHS) ve toplam bakteri sayısı sonuçlarının değerlendirilmesi, elde edilen sonuçların karşılaştırılması ve eksikliklerin ortaya konulması amaçlandı. Tekirdağ ilinin farklı bölgelerinde bulunan 50 farklı işletme ve çiğ süt toplama merkezi seçilerek, 150 mL’lik steril kaplara süt örnekleri alındı. Süt örneklerinde SHS ve toplam canlı bakteri sayısı ölçüldü. Tank sütü örneklerinin alındığı gün aynı işletmelerin çalışanlarına ya da işletme sahiplerine anket uygulaması yapılarak işletmede uygulanan mastitis kontrol programlarına ait bilgiler değerlendirildi. Alınan tank sütü örneklerinde SHS ortalamas1 560.204,08 $( \pm 12.399,769)$ hücre $/ \mathrm{mL}$, toplam canlı bakteri sayıs1 ortalama 1.796.718,36 $( \pm 156.573,31) \mathrm{kob} / \mathrm{mL}$ olarak tespit edildi. Yapılan anket ve laboratuvar analizleri sonrası işletmelerde sağım öncesi meme başlarının yıkanması, kurulanmas1, teat dipping, ön sağım ve ön sütün kontrolü, kuru dönem idaresi ve meme sağllğı kontrollerinin neredeyse hiç uygulanmadığ1 görüldü. Sonuç olarak, Tekirdağ ilinde bulunan aile tipi sütçü işletmelerde tank sütü SHS ve toplam canlı bakteri sayısının kabul edilebilir değerlerin üzerinde olduğu, bunun sebebinin işletmelerde uygulanmayan veya dikkat edilmeyen meme sağlığı kontrol programları olabileceği kanısına varıldı. Bu bölgedeki sütçü işletmelere meme sağlığını üst seviyelerde tutmak ve süt kalitesini en iyi düzeye getirebilmek amacıyla bu konuda yoğun eğitim seminerleri ve/veya bilgilendirme toplantılarının yapılmasının uygun olacağı kanaatine varild1.

Anahtar Kelimeler: İnek, tank sütü, somatik hücre sayısı, toplam bakteri sayıs1, mastitis kontrol programları

To cite this article: Tosun S. Baki Acar D. The Comparison of Milking Hygiene with Bulk Tank Somatic Cell Count and Total Bacterial Count in Dairy Herds in Tekirdag Province. Kocatepe Vet J. (2019) 12(3):292-299. 


\section{GİRİŞ}

Süt ineği işletmelerinde sıkça rastlanan mastitis, ciddi ekonomik kayıplara yol açan,süt kalitesini düşüren ve meme bezlerinin bakteriyel, kimyasal, travmatik veya termal hasarlara karşı verdiği yangısal tepkiler olarak tanımlanmaktadır.Tedavi maliyeti oldukça yüksek olan mastitis,süt ve süt ürünlerinin kalitesini ve saklama süresini olumsuz etkileyen istenmeyen bir hastalıktır (Baştan 2010, Vural ve ark. 2016). Oluşan yangının derecesine göre mastitisler subklinik ve klinik mastitis olarak sinıflandirılmaktadır. Subklinik formda meme yang1sı klinik belirtiye yol açmamakta, meme dokusunda ve sütte gözle görülebilen bir değişiklik olmamaktadır. Hastalık inekler arasında kolayca bulaşma göstermekte ve bu tip meme yang1ları sütçü işletmelerde maddi kayıplara sebep olan büyük problemler ortaya çıkartmaktadırlar. Klinik form ise gözle görülebilen semptomlara neden olarak hasta memede az veya çok şişlik, ağrı, sıcaklık artışı ve renk değişikliğine yol açmaktadır. Süt verimindeazalma hatta bazen tamamen kesilme; sütte sulanma veya pihtılaşma gibi bozukluklar ortaya ç1kabilmektedir(Blowey ve Edmondson 2010).

Somatik hücreler, vücudun doğal savunma sistemini oluşturan hücrelerdendir ve sağlıklı memeden alınan süt içeriğinde 200.000hücre/mL'nin altında bulunmaktadır. Tank sütünden alınan örneklerde kabul edilebilir SHS ise 400.000 hücre/mL'nin altındaki değerlerdir. Sütte bulunan somatik hücre sayısındaki değişimler, savunma sistemini uyaran ya da meme içi enfeksiyon olgusunaneden olan yangisal tepkinin bir sonucu olarak meydana gelmektedir. Sütteki somatik hücre sayısında görülen artışlar ile yanginın derecesi arasinda pozitif korelasyon mevcuttur (Küplülü ve Vural 2016). Sürü sağlığ1 programlarında kritik nokta, mastitisin mümkün olduğunca hılı belirlenmesi ve soruna yönelik strateji geliştirilmesidir. Sürüde mastitis varlığının belirlenmesinde kullanılan en önemli yöntemlerden birisi SHS'nın tespitidir. Bunun yanında, tank sütünden alınan örneklerdebakteri sayısının belirlenmesi de meme sağlı̆̆ının durumu ve süt kalitesinin ortaya konulmasinda güvenilir belirteçlerdendir. Aseptik koşullarda sağlıklı hayvanlardan sağılan sütün toplam bakteri sayısı düşüktür ve patojen bakteri içermemektedir. Çiğ süt örneklerinden steril şartlarda alınan numunelerde 1000 kob \mL'nin altındaki değerler çok iyi olarak tanımlanırken, $100.000 \mathrm{kob} \backslash \mathrm{mL}$ 'nin altındaki değerler kaliteli ve içilebilir olarak sınıflandırılmaktadır (Boor ve ark. 1998).

Meme enfeksiyonu olan bir ineği tedavi etmek, o ineği mastitise karşı korumaktan daha maliyetlidir. Bu sebeple işletmelerdeki tüm inekleri koruma altına alabilen ve "Mastitis Kontrol Program1" olarak adlandirılan bir program uygulanmalıdır. Farklı ülkelerde meme sağlığının korunması amacıyla kullanılan bu programların uygulanmas1 sonucunda işletmede düşük mastitis görülme oranı, süt kaybında azalma, iş gücü ihtiyacinda azalma ve tedavi giderlerinin minimuma düşürülmesi gibi olumlu sonuçlar bildirilmektedir (Honkanen-Buzalski ve Pyörala 1995, Gleeson ve ark. 2009, Blowey ve Edmondson 2010, Peterson-Wolfe ve ark. 2013, Vural ve ark. 2016). Hayvancllık yönünden gelişmiş ülkelerde mastitis sorununun ortadan kaldırılması amaciyla Ulusal Mastitis Konseyleri kurulmuştur ve Ulusal Mastitis Kontrol Programlan ile mastitisler önlenmeye çalışılmaktadır (Baştan 2010, Vural ve ark. 2016). Sütçü inek işletmelerinde mastitis kontrol programlarındaki 3 ana hedef 1)Mevcut enfeksiyonların eliminasyonu,2)Yeni enfeksiyonlardan korunma, 3) Memenin sürekli mastitis açısından izlemesi olarak belirtilmektedir. Meme sağllğı kontrol programı ile sürüde bulunan tüm ineklerin aynı anda koruma altına alınabilmesi sağlanabilmektedir. Meme sağlığ1 kontrol programlarının uzun süre uygulandığ sürülerde ise meme enfeksiyonlarından korunmanın \%80-90 oranında başarısağladığ1 görülmüştür (Petersson- Wolfe ve ark. 2013).

Sunulan çalışma ile Tekirdağ ilindeki aile tipi süt işletmelerinde uygulanan meme sağlı̆̆1 ve sağım hijyeni uygulamalarının incelenmesi, işletmelerden alınan tank sütü örneklerinde SHS ve toplam bakteri sayısı sonuçları değerlendirilmesi, elde edilen sonuçların karşılaştırılarak ortaya çıkan eksiklik ve hataların ortaya konulması amaçland.

\section{MATERYAL ve METOT}

\section{Süt Örneklerinin Alınması}

Çalışmada kullanılan tank sütü örnekleri Tekirdağ ilinde bulunan aile tipi süt işletmelerinden elde edildi. Tekirdağ ilinin farklı bölgelerinde bulunan 50 farklı işletme ve çiğ süt toplama merkezi seçilerek otomatik karıştırıcı ile sürekli karıştırılan içi soğutulmuş süt dolu tanklardan 150 mL'lik steril kaplarla steril bir şekilde süt örnekleri alındı. Alınan bu örnekler uygun saklama koşullarında depolanarak ( $4^{\circ} \mathrm{C}$ 'de muhafaza edilerek) 6 saat içerisinde laboratuvara ulaştırıldı.

\section{Tank Sütü Örneklerinde Somatik Hücre ve Toplam Bakteri Sayılarının Analizi}

Alınan süt örneklerinde SHS ve toplam bakteri sayısının analizi Tekirdağ Gıda Kontrol Laboratuvar Müdürlüğü Laboratuvarında Bentley FTS/FCM Combi 400 isimli cihaz kullanılarak yapılmışır.

\section{İşletmelere Uygulanan Anket Bilgileri}

Tank sütü örneklerinin alındığı gün aynı işletmelerin çalışanlarına, işletme sahiplerineya da süt toplama tankına süt döken işletmelerden seçilenlere anket uygulaması yapılarak, işletmede uygulanan mastitis kontrol programlarına ait uygulamalar değerlendirildi. $\mathrm{Bu}$ amaçla, yalnızca bu çalışma için orijinal anket 
soruları hazırlandı. Hazırlanan sorular açık uçlu sorular şeklinde planland.

Anketin ilk bölümünde işletme adı, adresi, çalışan personel sayısı (varsa) ve işletme türü gibi işletmeye ait genel bilgiler soruldu. İkinci bölümde, sürüdeki hayvan sayıs1, sürüdeki sağmal inek/düve sayıs1, günlük süt üretim miktarı, inek başına ortalama günlük süt üretim miktarı gibi işletmede bulunan hayvanlarla ilgili bilgiler toplandı. Üçüncü bölümde ise sağım sıklı̆̆1, sağım tipi (otomatik/yar1 otomatik/manuel), özel sağımhane bölümünün olup olmadığı, sağım sisteminin bakım sıklı̆̆1, sağım sisteminin temizlik rutini, ahırda kullanılan altlık tipi, dişardan hayvan girişinin olup olmadığı, ahıra ne sıklıkta hayvan girişi olduğu, antibiyotik kalıntısı nedenli süt iadesi/alınmaması durumunun varlığ1, kuruya çıkarılırken ineklere kuru dönem antibiyotik uygulamasının yapılıp yapılmadığı, sağım öncesi meme başlarının yıkanması ve kurulanması ile ilgili uygulamalar, sağım öncesi ön süt kontrolünün yapılıp yapılmadığı, sağım öncesi ve sonrası teat dipping uygulama rutini, sağım sürecinde tek kullanımlık eldiven giyilip giyilmediği, her bir inek için ortalama sağım süresi, sağım yapan kişi (sahibi/aile fertleri/sağım personeli) ve düzenli mastitis kontrolü varlığ1 gibi meme sağlığı kontrol programları ile ilişkili ve direkt etkileyebilecek konular hakkında bilgiler alındi.

\section{İstatistiksel Değerlendirme}

Çalışmada verilerin analizi Microsoft Excel ve Windows SPSS 20.0 Paket Programi (SPSS Inc., Chicago, IL, USA) ile yapıldı. Bu amaçla öncelikle nitel değişkenlerin frekans ve yüzde dağılımları alındı. Nicel değişkenler için ortalama, standart sapma (S.S.), minimum ve maksimum değerleri alındı. Değişkenler arasındaki ilişkilerde, nicel değişkenler arasındaki ilişkiler için korelasyon, nitel ve nicel değişkenler arasındaki ilişkilerde iki grup için bağımsız örneklemler için t testi kullanıldı.

\section{BULGULAR}

\section{Tank Sütü Somatik Hücre Sayıs}

Tekirdağ ilinde bulunan 50 adet sütçü işletmeden alınan tank sütü örneklerinde SHS ortalaması

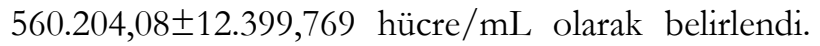
Tank sütü SHS'nin minimum 535.000 hücre/mL ve maksimum 596.000 hücre $/ \mathrm{mL}$ düzeylerinde olduğu görüldü (Tablo 1).

\section{Tank Sütü Toplam Bakteri Sayısı}

Steril şartlarda ve steril örnek kaplarına alınan tank sütlerinde toplam bakteri say1s1 ortalama 1.796.718,36士156.573,31 kob/mL olarak tespit edildi. Toplam bakteri sayisinin minimum 1.577 .000 $\mathrm{kob} / \mathrm{mL}$, maksimum ise $2.138 .000 \mathrm{kob} / \mathrm{mL}$ olduğu belirlendi (Tablo1).
İşletmelere Uygulanan Anket Sonuçları

Çalışma materyallerinin alındığı işletmelerin tamamı, hayvan sayıları 1 ile 369 arasında değişen (ortalama 38,86 hayvan) aile tipi işletmelerden oluşmaktadır. Ticari işletmelerden de örnek alınmak istenmesine rağmen, bu işletmelerde genel kural olarak personel dışı giriş-çıkış ve örnek alımının yasak olması nedeniyle örnek alınmas1 mümkün olmadı. İşletmelerde sağmal inek sayısı ortalama 19,74 (min:1 inek; max:200 inek) olarak belirlenirken, günlük süt üretim miktar1 ortalama 347,24 litre (min:22 litre; max:3.000 litre) ve inek başına ortalama günlük süt üretim miktar1 23,20 litre (min:19; max:25 litre) olarak tespit edildi (Tablo1).

İşletmelerde çalışan personel sayısı sorusuna verilen yanttlar değerlendirildiğinde, 50 işletmenin 43'ünde herhangi bir personel çalışmadığı ve tüm işlemlerin aile fertleri tarafindan gerçekleștirildiği, 7 işletmede ise yalnızca 1 adet personel çalıştığı öğrenildi. İşletmelerin tamamında sabah-akșam olmak üzere günde 2 kez sağım yapıldığ1; 41 adet işletmede yarı otomatik sistem ve 9 adet işletmede otomatik sağım sistemlerinin kullanıldığı; yalnızca 10 adet işletmede özel sağımhane bölümünün bulunduğu ve diğer 40 işletmede herhangi bir sağımhane bölümünün olmadığı belirlendi (Tablo 2).

Sağım sisteminin bakım sıklı̆̆ının ortalama 6,66 ayda bir kez (min:1 ay, max:12 ay) olduğu ve sağım sisteminin temizlik rutininin 26,4 günde bir kez (min:1 gün, max: 42 gün arayla) gerçekleştirildiği tespit edildi. Ahırda kullanılan altık tipi olarak en sık saman tercih edildiği, az miktarda talaş tercihi olduğu ve meraya çıkarmanın da uygulandığı görüldü. İşletmeye dışarıdan hayvan girişinin neredeyse hiç olmadığı, yalnızca 2 işletme sahibinin dışarıdan 1-2 yılda bir kez hayvan aldığ1 ve geri kalan işletmelerde sürekli kendi buzağılarının yetiştirildiği tespit edildi. Sağılan sütlerde antibiyotik kalıntısı nedeniyle sütün iadesi/alınmaması gibi bir sorunla karşılaştınız m1 sorusuna tüm işletmeciler tarafından "Hayır" yanıtı verildi. Bununla birlikte, ineklerin kuruya çıkartılması sırasında işletmelerin hiçbirinde meme içi kuru dönem antibiyotik uygulaması yapılmadı̆̆ belirlendi. Sağım sürecinde uygulanması gereken meme sağllğı kontrol programları ile ilgili anket soruları da değerlendirildi. Buna göre, sağım öncesi meme başlarının yıkanması işlemini yalnız 12 işletmenin rutin olarak uyguladığı ve bu işletmelerden de sadece birinin yıkama sonrası meme başlarının kurulanmasına dikkat ettiği, diğer işletmelerde meme başlarının yıkama sonrası kurulanmadan direkt sağım başlıklarının takıldığı tespit edildi. Ayrıca kurulama işlemini yaptığını söyleyen işletme görevlisinin, her inek için ayr1 bir kurulama bezi ya da kağıt havlu kullanmadığı ve ineklerin tamamının meme başlarının aynı bez ile kurulandığı belirlendi. Sağım işlemi sırasında sağımı yapan kişilerin hiçbir şekilde tek kullanımlık eldiven giymediği, sağım öncesi ve sağım sonrası teat dipping 
işleminin işletmelerin hiçbirinde uygulanmadığı ve sağım öncesinde ön sütün sağılarak kontrol edilmesi işlemini yalnızca bir işletmenin gerçekleştirdiği ortaya konuldu. Ayrıca 43 işletmede sağımın işletme sahibi veya aile bireyleri tarafindan gerçekleştirildiği, 7 işletmede sağım personelinin sağımla ilgilendiği görüldü. İşletmelerden birinde günlük rutin kontrol şeklinde mastitis kontrolünün yapıldı̆̆1 bildirilirken, geri kalan işletmelerde düzenli aralıklarla mastitis kontrolü yapılmadığ ve hastalık ortaya çıkması durumunda kontrollerin yapıldığı belirlendi (Tablo 2). Her bir inek için sağım süresinin kaç dakika sürdüğü sorusuna verilen cevaplarda ortalama sürenin 7,98 dakika olduğu ve 3 dakika ile 9 dakika arasında değiştiği sonucuna ulaşıldı (Tablo 1).

\section{İşletme Özellikleri, Mastitis Kontrol Programlarının Uygulanma Alışkanlıkları, SHS ve Toplam Bakteri Sayısı Arasındaki Korelasyon Bulgular1}

İşletmelerden alınan anket sonuçları ile tank sütü SHS ve toplam bakteri sayıları arasindaki korelasyonlar değerlendirildi (Tablo 3). Buna göre, inek başına ortalama günlük süt üretim miktarı ile SHS arasında pozitif bir korelasyon bulunurken, sağım sisteminin bakım sıklığ ve her bir inek için ortalama sağım süresi ile SHS arasinda negatif bir korelasyon olduğu tespit edildi $(p<0,05)$. Sağım sisteminin bakım sıklı̆ı ve ortalama sağım süresi ile toplam bakteri sayısı arasında da, SHS'de olduğu gibi negatif korelasyon belirlendi $(\mathrm{p}<0,05)$. İşletmedeki hayvan sayısı ve sağmal inek sayısı ile bakım sıklı̆ı arasında negatif korelasyon orta derecede önemli bulunurken $(\mathrm{p}<0,05)$, yine hayvan sayısı ve sağmal inek sayısı ile ortalama sağım süresi arasında yüksek derecede önemli korelasyon belirlendi $(\mathrm{p}<0,01)$.

Tablo 1. Nicel değişkenlere ilişkin bulgular $(\mathrm{n}=50)$

Table 1. Results of quantitative variables $(n=50)$

\begin{tabular}{lcccl}
\hline Değişkenler & Min & Max & Ortalama \pm S.S. & Birim \\
\hline SHS & 535.000 & 596.000 & $560.204 \pm 12.399,769$ & Hücre $/ \mathrm{mL}$ \\
Toplam bakteri sayısı & 1.577 .000 & 2.138 .000 & $1.796 .718,36 \pm 156.573,31$ & Kob/mL \\
Hayvan sayısı & 1 & 360 & $38,86 \pm 58,22$ & Adet \\
Sağmal inek sayısı & 1 & 200 & $19,74 \pm 30,83$ & Adet \\
Günlük süt üretim miktarı & 22 & 3000 & $347,24 \pm 520,07$ & Litre \\
İnek başına ort. Günlük süt ürerim miktarı & 19 & 25 & $23,20 \pm 1,76$ & Litre \\
Ortalama sağım süresi & 3 & 10 & $7,98 \pm 2,42$ & Dakika \\
\hline
\end{tabular}

Tablo 2. Nitel (Kategorik) değişkenlere ilişkin bulgular

Table 2. Results of qualitative variables

\begin{tabular}{|c|c|c|c|}
\hline Değişkenler & & Frekans (f) & $\%$ \\
\hline \multirow{2}{*}{ İşletme Türü } & Aile Tipi İşletme & 50 & 100 \\
\hline & Ticari Tip İşletme & - & - \\
\hline \multirow{2}{*}{ Personel Varllğ1 } & Var & 43 & 86,0 \\
\hline & Yok & 7 & 14,0 \\
\hline \multirow{2}{*}{ Sağım Sıklı̆̆ } & 2 Sağım & 50 & 100 \\
\hline & 3 Sağım & - & - \\
\hline \multirow{2}{*}{ Sağım Tipi } & Yarı Otomatik & 41 & 82,0 \\
\hline & Otomatik & 9 & 18,0 \\
\hline \multirow{3}{*}{ Sağımhane Bölümü } & Var & 10 & 20 \\
\hline & Yok & 40 & 80,0 \\
\hline & Yok & 48 & 96,0 \\
\hline \multirow[t]{2}{*}{ İşletmeye Hayvan Girişi } & Yilda Bir Kez & 1 & 2,0 \\
\hline & İki Yılda Bir Kez & 1 & 2,0 \\
\hline \multirow{2}{*}{ Antibiyotik Kalıntısı Nedeniyle Süt İadesi } & Var & - & - \\
\hline & Yok & 50 & 100 \\
\hline \multirow{2}{*}{ Kuru Dönem Antibiyotik Uygulaması } & Var & - & - \\
\hline & Yok & 50 & 100 \\
\hline \multirow{2}{*}{ Sağım Öncesi Meme Başlarının Yıkanması } & Var & 12 & 24,0 \\
\hline & Yok & 38 & 76 \\
\hline \multirow{2}{*}{ Meme Başlarının Kurulanması } & Var & 1 & 2,0 \\
\hline & Yok & 49 & 98,0 \\
\hline \multirow{2}{*}{ Sağım Yapan Kişi } & Sağım Personeli & 7 & 14,0 \\
\hline & Aile Fertleri & 43 & 86,0 \\
\hline \multirow{2}{*}{ Düzenli Mastitis Kontrolü } & Var & 1 & 2,0 \\
\hline & Yok & 49 & 98,0 \\
\hline
\end{tabular}


Tablo 3. İşletme Özellikleri, Mastitis Kontrol Programlarının Uygulanma Alıskanlıkları, SHS ve Toplam Bakteri Sayısı Arasindaki Korelasyon Bulgular1

Table 3.Significant correlation coefficients $\left(\mathrm{r}^{\mathrm{a}}\right)$ of the operation characteristics, mastitis control programs routines, SCC and Total bacterial counts

\begin{tabular}{|c|c|c|c|c|c|c|c|c|c|}
\hline & SHS & $\begin{array}{c}\text { Total Canlı } \\
\text { Bakteri } \\
\text { Sayısı }\end{array}$ & $\begin{array}{c}\text { Hayvan } \\
\text { Sayıs1 }\end{array}$ & $\begin{array}{c}\text { Sağmal } \\
\text { İnek Sayısı }\end{array}$ & $\begin{array}{l}\text { Toplam } \\
\text { Günlük Süt } \\
\text { Üretimi }\end{array}$ & $\begin{array}{c}\text { İnek Başına } \\
\text { Günlük Süt } \\
\text { Üretimi }\end{array}$ & $\begin{array}{c}\text { Sağım } \\
\text { Sisteminin } \\
\text { Bakım Sıklığı }\end{array}$ & $\begin{array}{c}\text { Sağım } \\
\text { Sisteminin } \\
\text { Temizlik Rutini }\end{array}$ & $\begin{array}{l}\text { Sağım } \\
\text { Süresi }\end{array}$ \\
\hline SHS & - & 0,007 & 0,128 & 0,137 & 0,114 & $0,289^{*}$ & $-0,138$ & 0,115 & $-0,094$ \\
\hline Total Canlı Bakteri & 0,007 & - & 0,035 & 0,036 & 0,020 & $-0,162$ & $-0,254^{*}$ & $-0,080$ & $-0,279^{*}$ \\
\hline \multicolumn{10}{|l|}{ Say1s1 } \\
\hline Hayvan Sayısı & ,128 & 0,035 & - & $0,986^{* *}$ & $0,953^{* *}$ & $0,281^{*}$ & $-0,251^{*}$ & 0,061 & $-0,645^{* *}$ \\
\hline Sağmal İnek Sayısı & 0,137 & 0,036 & $0,986^{* *}$ & - & $0,960^{* *}$ & $0,290^{*}$ & $-0,285^{*}$ & 0,060 & $-0,623^{* *}$ \\
\hline Toplam Günlük Süt & 0,114 & 0,020 & $0,953^{* *}$ & $0,960^{* *}$ & - & $0,338^{* *}$ & $-0,234$ & 0,057 & $-0,666^{* *}$ \\
\hline \multicolumn{10}{|l|}{ Üretimi } \\
\hline \multicolumn{10}{|l|}{ Süt Üretimi } \\
\hline Sağım Sisteminin & $-0,138$ & $-0,244^{*}$ & $-0,251^{*}$ & $-0,285^{*}$ & $-0,234$ & $-0,098$ & - & $0,258^{*}$ & $0,345^{* *}$ \\
\hline \multicolumn{10}{|l|}{ Bakım Sıklığ1 } \\
\hline Sağım Sisteminin & 0,115 & $-0,080$ & 0,061 & 0,060 & 0,057 & 0,140 & $0,258^{*}$ & - & $-0,133$ \\
\hline \multicolumn{10}{|l|}{ Temizlik Rutini } \\
\hline Sağım Süresi & $-0,094$ & $-0,279^{*}$ & $-0,645^{* *}$ & $-0,623^{* *}$ & $-0,666^{* *}$ & $-0,346^{* *}$ & $0,345^{* *}$ & $-0,133$ & - \\
\hline
\end{tabular}

\section{TARTIŞMA}

İnsanların dengeli vücut gelişiminin sağlanabilmesi ve sağlıklı kalmanın sürdürülebilmesi için en gerekli besin maddeleri hayvansal proteinlerdir. Hayvansal protein kaynakları arasında en sık tüketilenler ise et, süt ve yumurtadır. Tüm dünyada artan hayvansal gida ihtiyacının karşılanabilmesi için hayvancılıkla ilgili yoğun araştırmalar yapılmakta, hem hayvan sayısının artırilması hem de elde edilecek hayvansal ürünlerin etkin ve yüksek oranda sağlanabilmesi için çaba harcanmaktadır (Akman ve ark. 2010, Elmadfa ve Meyer 2017). İnsanlar tarafindan tüketilen hayvansal gidalar arasında büyük oranda sığır eti ve inek sütü bulunmaktadır. Dünya üzerindeki büyükbaş hayvan sayısına bakıldığında, 2016 yllı Birleşmiş Milletler Gida ve Tarım Örgütü (FAO) verilerine göre 1.674.168.000 baş büyükbaş hayvan olduğu ve bu hayvanlardan elde edilen süt üretiminin ise 659.150.049 ton olduğu bilinmektedir. Ülkemizdeki süt sı̆̆ırccllğının mevcut durumu incelendiğinde 2018 yllı saf kültür, kültür melezi ve yerli ırk süt sığırı (inek ve düve) toplam sayısinın 9.682.621 adet olduğu ve süt ürünleri üretiminin hayvan sayısı artışılla doğru olarak her geçen y1l arttığı bildirilmektedir (TÜİK 2019).

Sütçü işletmelerde bulunan hayvan sayılarına göre işletme büyüklükleri belirlenmektedir. Avrupa Birliği’nde yer alan ülkelerde, 2005 yllı verilerine göre tüm işletmeler arasında 50 ve daha fazla sayıda inek bulunan işletmelerin oranı $\% 10$ 'dan daha az sayıdadır ve bu ülkeler arasında İngiltere, Hollanda, Danimarka ve Çekoslovakya yer almaktadır. Genel ortalama değerlendirildiğinde ise Avrupa Birliği ülkelerinde issletmelerde bulunan ortalama inek sayısı 8,9'dur. Türkiye'de de benzer bir durum söz konusudur, hayvancilık işletmelerinin büyük çoğunluğu küçük/orta ölçekli aile ișletmeleridir ve bu işletmelerde bulunan ortalama inek sayısı 4 baş civarındadır (Akman ve ark. 2010). Sunulan çalışmada Tekirdağ ilinden süt örneği alınan işletmelerin \% $\% 2$ 'si 50 baştan daha az inek sayısına sahip küçük ve orta ölçekli aile işletmeleridir ve il genelinde bulunan süt ișletmelerinin genel dağılımı da benzer özellik göstermektedir.

Kaliteli süt denildiğinde akla düşük somatik hücre ve bakteri sayısina sahip, antibiyotik kalıntısı bulunmayan, katkısız süt gelmektedir. Somatik hücre sayıs1 ise çiğ sütün kalitesinin ve meme sağllğ1 durumunun değerlendirilmesinde en etkili ve s1k kullanilan parametredir (Akers 2002, Wustenberg 2009). Bireysel SHS'nın 250.000 hücre/mL düzeyinden yüksek olması inekte meme içi enfeksiyon varlığı ihtimalini akla getirirken, tank sütünde ölçülen SHS'nin 400.000 hücre/mL'den yüksek olmas1 halinde o işletmede meme sağlığı sorunlarının olduğu ve sağmal ineklerin bu konuda kontrol edilerek gerekli önlemlerin alınması gerektiği düșünülmelidir. Bununla birlikte meme sağllğı ve süt kalitesi değerlendirmesinde tank sütü SHS düzeylerinin geçmişten günümüze ülkeler arasında değişiklik gösterdiği; ABD'nde $<750.000$ hücre/mL, Kanada'da $<500.000$ hücre/mL ve Avrupa Birliğinde $<400.000$ hücre/ $\mathrm{mL}$ ideal düzeyler olarak sayılırken, son yıllarda bu değerler daha da aşağı çekilerek 200.000 hücre/mL'nin altında bulunan SHS'nın halk sağlı̆̆ ve 
süt ürünlerinin kalitesi açısından daha doğru olacağ1 bildirilmektedir (Baştan 2010, Vural ve ark. 2016). Çalışmamızda tank sütü örneklerinin SHS değerleri ortalama 560.204,08 hücre/mL olarak saptanmıştır ve bu düzey olması gereken değerin oldukça üzerinde olduğu tespit edilmiştir. Tank sütü kalitesi hakkında gerçekleştirilen araştırmalarda farklı ülkelere ait SHS sonuçları değerlendirildiğinde, ABD ve Avrupa ülkelerinde tank sütü SHS değerlerinin çoğunlukla 400.000 hücre $/ \mathrm{mL}$ düzeyinin çok altında olduğu, daha eski yıllarda yapılan araştırmalarda bu değerin bir miktar üzerine çıkabilen sonuçlar (Hollanda, 422.000 hücre/mL) bildirildiği ancak zamanla işletme büyüklüklerinin artması, hijyen uygulamalarının rutin uygulama haline gelmesi gibi nedenlerle SHS değerinin 250.000 hücre/mL'nin altında tutulmasının başarıldığ1 görülmektedir (Barkema ve ark. 1998, Pantoja ve ark. 2009, Zucalli ve ark. 2011). Bununla birlikte Darbaz ve ark. (2018) tarafindan Kuzey Kıbris Türk Cumhuriyeti'nde gerçekleştirilen bir çalışmada, araştırmamıza benzer olarak tank sütü SHS ortalama 521.583 hücre/mLdüzeyinde belirlemişler ve çalışmamızda bildirdiğimiz gibi sağım hijyeni, meme sağlığ1 kontrolleri vb. idarecilik uygulamalarında tespit ettikleri eksikliğe bağlı olarak Kuzey Kıbrıs Türk Cumhuriyeti'nde SHS'nin yüksek seyrettiğini tespit etmişlerdir.

Çiğ süt kalitesinin bir diğer belirteci de sütteki toplam bakteri sayısıdır. Süt ve süt ürünleri insanlar için önemli bir hayvansal protein kaynağı olmakla birlikte, süt içinde bulunan patojen bakteri sayısı ve türü sağlık açısından önemli sorunlara yol açabilmektedir. Bu nedenle süt kalitesinin belirlenmesi amaciyla yapılmas1 gereken bakteriyolojik testler Amerika Halk Sağllğ1 Birliği tarafindan ortaya konulmuştur (Marshall 1992). Kaliteli ve içilebilir çiğ sütte toplam bakteri sayısının $100.000 \mathrm{kob} / \mathrm{mL}$ düzeyinin altında olmas1 beklenmektedir. Bu standart değerin altında bakteri sayısına sahip sütlerin pastörizasyonu sirasinda patojen bakteriler başarıly yok edilmekte ve insan sağlı̆̆ üzerine zararı olmamaktadır (Boor ve Murphy 2002, Murphy ve ark. 2016). Sütteki toplam bakteri say1s1 spesifik bakteri gruplarından (termodurik, psikrotrofik ve çevresel mastitis patojenleri) etkilenmekte ve bakteri sayısındaki artışla birlikte bakteriyel mikroflora kompozisyonunda çok fazla değişiklik olmaktadır. Ayrıca tank sütü toplam bakteri sayısı mevsim, kullanılan sağım sistemi, meme sağlı̆̆1 kontrol programları uygulamaları, altlık tipi, meme baş1 temizliği gibi birçok faktörden etkilenmektedir. Gelişmiş ülkelerde sütçü işletmelerin yeterliliği, kuruluş ve işleyiş şartları çok iyi düzeylere ulaştı̆̆ından SHS seviyesinde olduğu gibi toplam bakteri sayısında da standartların oldukça altına inmişler ve 10.000 $\mathrm{kob} / \mathrm{ml}$ 'nin altındaki rakamlara ulaşmışlardır (Jones ve Sumner 1999, Jayaro ve ark. 2004, Zucali ve ark. 2011). Sunulan çalışmada toplam canlı bakteri sayısı ortalama 1.796.718,36 kob/mL düzeyinde bulunurken, alınan örnekler arasında en düşük değer
1.577.000 kob/mL olarak saptand1 ve bu değerlerin standart toplam canlı bakteri sayısının çok üzerinde olduğu görüldü. Çalışmada örnek alınan tank sütlerinde bakteri sayılarının bu kadar yüksek çıkmasının nedenleri arasında işletmelerin aile tipi işletme olması ve mastitis kontrol programları hakkında çok yetersiz bilgiye sahip olmaları ya da hiçbir fikirlerinin olmaması, ahır ve sağım şartlarının yetersizliği, akşam sağılan sütün süt toplama tankında bekletilerek ertesi sabah sağımda toplanan sütle birlikte teslim edilmesi ve bu arada tank sütünde mikrobiyolojik üremenin artması gibi faktörlerin etkili olabileceği kanısına varıldı.

Sütçü işletmelerde süt kalitesi, hayvan sağllğı, antibiyotik kalıntı problemi gibi insan ve hayvan sağlı̆̆1 ile ekonomiyi direkt olarak etkileyen en önemli sorun mastitistir. Mastitisin neden olduğu yüksek SHS ve toplam bakteri sayısına bağlı olarak tüm dünyada çok ciddi ekonomik kayıplar ortaya ç1kmaktadır. Mastitis nedenli ekonomik kayıpların önüne geçmek amaciyla ABD, Hollanda ve Fransa gibi dünyada önemli süt üretimi yapılan ülkelerde "Ulusal Mastitis Kontrol Konseyleri" kurularak ülke çapında sorunun belirlenmesi, doğru tanının konulması, önleyici stratejilerin geliştirilmesi ve mastitise bağlı ekonomik kayıpların azaltılmasına yönelik büyük adımlar atılmıştır (NMC 1996, Barnouin ve ark. 2004, Jansen ve ark. 2010, Lam ve ark. 2013). Bu amaçla ahır ve çevrenin düzenlenmesi, sağım sürecinin doğru idaresi, sağım ekipmanlarının bakım ve temizliği, meme başlarının temizliği ve sağım öncesi/sonrası teat dipping uygulaması, memenin mastitis yönünden izlenmesi, kuru dönem yönetimi gibi kritik önlemler ve uygulamalar üzerinde durulmaktadır. Yapılan araştırmalar belirtilen bu önlemler ve uygulamaların gerçekleştirilmesi sonucu süt SHS ve toplam bakteri sayısında ciddi düşüş görüldüğünü, süt kalitesinde sürdürülebilir artış kaydedildiğini ve ekonomik kayıpların önemli oranda azaltıldığını ortaya koymaktadır (Barkema ve ark. 1998, Sharif ve ark. 2009, Bava ve ark. 2011). Ülkemizin farkl bölgelerinde gerçekleştirilen farklı çalışmalarda SHS ve toplam bakteri sayısı düzeyleri ile süt kalitelerinin hijyen, bakım, sağım ve sağım sistemine bağlı faktörler nedeniyle yeterli kalite düzeyine ulaşamadığ1 ve geliştirilmesi gereken noktalar olduğu bildirilmiştir (Önal ve Özder 2007, Patır ve ark. 2010, Koçyiğit ve ark. 2016). Sunulan çalışmada, yukarıda bildirilen çalışmalara paralel olarak anket soruları hazırlandı ve Tekirdağ ilinde bulunan sütçü işletmelerde mastitis kontrol programları hakkındaki bilgi düzeyleri, programın uygulanma düzeyi ve rutini, işletmeye, sağım sistemlerine ve sağım düzenine ilişkin bilgiler sorularak meme sağlığı düzeyi hakkında bilgi alındı.

Mastitis kontrol programları kapsamında ilk dikkate alınan başlık işletme ve ahırın mevcut durumunun değerlendirilmesidir. Araştırmalar göstermektedir ki büyük ölçekli ve endüstriyel tipte işletmelerde tank 
sütü SHS ve toplam bakteri sayıları, küçük ve orta ölçekli aile işletmelerine oranla daha düşük seyretmektedir. Büyük işletmelerde hayvan sayısı arttıkça sistemde otomatikleşme tercih edilmekte, sağım personelinin eğitim düzeyi artmakta ve kontrol mekanizmaları daha ciddi işlemektedir. Aile tipi ve az sayıda inek bulunan işletmelerde ise hayvan sayısı az olduğu için elle ya da yarı otomatik sistemlerle sağım yapilmakta, geleneksel yöntemler ve bilgi düzeyi ile aile fertleri tarafindan işler sürdürülmekte ve mastitis kontrolüne yönelik uygulamalara önem verilmemekte, sonuç olarak da mastitis görülme oranı artmakta ve tedavi başarısı düşmektedir (Jayaro ve ark. 2004, Jansen ve ark. 2010, Lam ve ark. 2013). Çalışmamızda süt örneği aldığımız işletmeler küçük ve orta ölçekli aile tipi işletmelerden oluşmaktadır. Bu işletmelerde ortalama hayvan sayısı 38 adet iken sağmal inek sayısı ortalama 19 idi ve büyük çoğunluğunda personelin bulunmadığı, tüm işlemlerin aile fertleri tarafından gerçekleştirildiği belirlendi. İşletmede bulunan kişilere uyguladığımız anket sonucunda, ilgili kişilerin ineklerde mastitisin önlenmesi amaciyla alınacak önlemler, düzeltmeler ve kontrol programları hakkında neredeyse hiç bilgisi olmadığı sonucuna ulaşıldı. Mevcut durum değerlendirildiğinde farklı araştırmacılar tarafindan daha önce yapılmış çalışmaları destekler nitelikte, küçük ölçekli işletmelerde bilgi düzeyinin yetersizliğine bağlı uygulama hataları olduğu ve bunun sonucunda süt SHS ve toplam bakteri sayılarının kabul edilebilir değerlerin çok üzerinde seyrettiği belirlendi.

Sağım sistemi ve sağ1m süreci ineklerde mastitis oluşumunda direkt etkili faktörler arasındadır. Sağım sisteminin tipi, özel sağımhane bölümü, sağım sisteminin bakım sıklığ1 ve temizlik rutini, sağım öncesi meme başlarının yikanıp kurulanması, sağım öncesi ve sonrası teat dipping uygulamaları gibi birçok parametre doğru olarak seçildiğinde ve yapıldığında meme sağlığ1 sorunları azalmakta, süt SHS ve bakteri sayısında ciddi düşüşler gözlenmektedir (Baştan, 2010). Sağım makinesinin otomatik tipte olmas1, elle sağım ve yarı otomatik tipe göre süt SHS'nın azalmasına ve meme sağlı̆̆ının olumlu yönde gelişmesine neden olmaktadır. Ancak sağım sistemi ne tipte olursa olsun kontrol ve bakımlarının düzenli yapılmaması ve temizlik rutinlerine dikkat edilmemesi sistem içinde patojen mikroorganizmaların üremesine, vakum/pulzasyon oranlarındaki düzensizlikler gibi bozuklukların meme başı hasarlarına ve meme içi enfeksiyon oranında artışa yol açması kaçınılmazdır (Köker ve Erdem 2016). Sağım sirasında tek kullanımlık eldiven giyilmesi, sağımcı tarafindan patojen etkenlerin taşınması ve bulaştırılmasını en aza indirmektedir. Sağım öncesinde meme başlarının yeterince temizlenmemesi ve gübreyle bulaş1k halde sağıma alınması fekal kontaminasyon riskini artırmakta ve süt kalitesini olumsuz etkilemektedir; ayrıca sağım öncesi meme başlarının yıkanarak her inek için temiz bir bez veya kağıt havlu ile kurulanması sütün indirilmesine de hazırlık imkanı vermektedir. $\mathrm{Bu}$ sırada ön sütün sağılarak muayenesinin yapilması ile hem klinik enfeksiyon kontrolünün yapılmasını sağlamakta hem de sütün indirilmesini uyarmaktadır. Meme başlarının temizliği ve önsütün muayenesi ile meme sağıma hazırlanırken hızlı hareket edilmeli ve sağım başlıkları yaklaşık 90 saniye içinde takılmalıdır. Oksitosin meme bezi üzerinde yaklaşık 8 dakika etkisini göstermektedir, bu nedenle sütün memeden tam olarak indirilebilmesi için bu sürelerin takibi önemlidir (Pantoja ve ark. 2009, Köker ve Erdem 2016). Mastitis kontrol programlarının önemli bir basamağı da sağım öncesi ve sonrası teat dipping uygulamasıdır. Çevresel ve kontagiyöz etkenlere bağlı mastitislerin önlenmesinde sprey formundan ziyade daldırma metodu ile sağım öncesi ve sonrası teat dipping uygulamalarının çok etkili olduğu belirtilmektedir (Chambers 2002, Jayaro ve ark. 2004). Sunulan çalışmada işletme sahiplerine ve sağım süreci ile ilgilenen kişilere yapılan ankette, yukarıda belirtilen kontrol programlar1 parametreleri hakkinda sorular soruldu. Anket bulgular1 değerlendirildiğinde, işletmelerin genelinde yar1 otomatik sağım sisteminin kullanıldığı, ayrı bir sağımhane bölümünün olmadığı, sağım öncesi meme başlarının yıkanma ve kurulanma oranının çok düşük olduğu, sağım öncesi ve sonrası teat dipping uygulamasının ise hiç yapılmadığı görüldü. Bu nedenle Tekirdağ ilinde bulunan aile işletmelerinin meme sağlığ1 kontrol programları hakkındaki bilgi düzeylerinin çok düşük olduğu ya da bilseler dahi uygulama konusunda isteksiz oldukları belirlendi. Mevcut anket sonuçları ile tank sütü SHS ve toplam canlı bakteri sayısı sonuçlarının birbiri ile uyum gösterdiği, standart değerlerin çok üzerinde bulunan SHS ve toplam bakteri sayılarının ahır şartları, sağım hijyeni ve sağım sistemlerinin bakımsızlı̆̆1 gibi nedenlere bağlı olarak, daha önce yapılan araştırmaları da destekler nitelikte (Chambers 2002, Jayaro ve ark. 2004, Pantoja ve ark. 2009, Baştan 2010, Küplülü ve Vural 2016) insan sağllğ̣ ve süt kalitesi yönünden uygun olmadığ1 tespit edildi.

Sonuç olarak, Tekirdağ ilinde bulunan küçük ve orta ölçekli aile tipi sütçü işletmelerde meme sağllğıkontrol programlan hakkındaki bilgi ve uygulama düzeylerinin yetersiz olduğu ve buna bağlı olarak SHS ve toplam bakteri sayısının standart değerlerin üzerinde seyrettiği belirlendi. Tekirdağ ilinde gerek Tarım ve Orman Bakanlığı'nın ilgili bölümlerince, gerekse bölge üniversitelerinin ilgili bölümlerinde görevli öğretim üyeleri ve bölge Veteriner Hekimler Odaları tarafindan meme sağlığını üst seviyelerde tutmak ve süt kalitesini en iyi düzeye getirebilmek amaciyla bu konuda yoğun eğitim seminerleri ve/veya bilgilendirme toplantılarının yapılmasının uygun olacağ1 kanaatine varıldı. 


\section{TEŞEKKÜR}

Bu çalışma ilk yaz̧arn Yükesek Lisans tez̧inden özetlenmistir.

Bu çalışma Afyon Kocatepe Üniversitesi Bilimsel Araștirma Projeleri Koordinasyon Birimi tarafindan desteklenmistir (Proje No: 18.SAG.BIL.27).

\section{KAYNAKLAR}

Akers RM. Lactation and The Mammary Gland, 1st Edition. Blackwell Publishing Company, Iowa, USA, 2002.

Akman N, Tuncel E, Tüzemen N, Kumlu S, Özder M, UlutaşZ. Türkiye Sığırcılık İşletmelerinin Yapısı ve Geleceğin Sığırcılık İşletmeleri. TMMOB Ziraat Mühendisleri Odası, Ziraat Mühendisliği VII. Teknik Kongresi, Bildiriler Kitab1 2, 11-15 Ocak 2010, Ankara, s: 651-665.

Barkema HW, Schukken YH, Lam TJGM, Beiboer ML, Benedictus G, Brand A. Management Practices Associated with Low, Medium, and High Somatic Cell Counts in Bulk Milk, J Dairy Sci, 1998; 81(7): 1917-1927.

Barnouin J, Chassagne M, Bazin S, Boichard D. Management Practices from Questionnaire Surveys in Herds with Very Low Somatic Cell Score Through a National Mastitis Program in France. J Dairy Sci. 2004; 87:3989-3999.

Baştan A. İneklerde Meme Sağllğı ve Sorunları. Kardelen Ofset Matbaacilık, Ankara, 2010.

Bava L, Zucalli M, Sandrucci A, Brasca M, Vanoni L, Zanini L, Tamburini A. Effect of cleaning procedure and hygienic condition of milking equipment on bacterial count of bulk tank milk. J Dairy Res. 2011; 78: 211-219.

Blowey R, Edmondson P. Mastitis Control in Dairy Herds 2nd Edition. CAB International, Oxfordshire,UK, 2010

Boor KJ,Brown DP, Murphy SC, Kozlowski SM, Bandler DK. Microbiological and chemical quality of raw milk in New York State. J Dairy Sci. 1998; 81(6): 1743-1748.

Chambers, JV. The Microbiology of Raw Milk in Dairy Microbiology Handbook. 3rd ed. R. K. Robinson. John Wiley \& Sons, Inc., New York. 2002; pp: 39-90.

Darbaz İ, Baştan A, Salar S. Investigation of udder health and milk quality parameters of dairy farms in Northern Cyprus. Part I: SCC and bacteriologic examination. Ankara Üniv Vet Fak Derg, 2018; 65:145-154.

Elmadfa I, Meyer AL. Animal proteins as important contributors to a healthy human diet. Annu Rev Anim Biosci.2017; 5:4.1-4.21.

Gleeson D, O'Brien B, Flynn J, O'Callaghan E, Galli F. Effect of pre-milking teat preparation procedures on the microbial count on teats prior to cluster application. Irish Vet J. 2009; 62: 461- 467

Honkanen-Buzalski T, Pyölara S. Monitoring and Management of Udder Health at the Farm. In: Sandholm M, Honkanen-Buzalski THY Kaartinen L, Pyörala S. Eds. The Bovine Udder and Mastitis. University of Helsinki, Finland, 1995; pp: 332-3378.

Jansen, Schaik V, Renes RJ, Lam TJGM. The effect of a national mastitis control program on the attitudes, knowledge, and behavior of farmers in the Netherlands. J Dairy Sci. 2010; 93: 5737-5747.
Jayaro BM, Pillai SR, Sawant AA, Wolfgang DR, Hedge NV. Guidelines for Monitoring Bulk Tank Milk Somatic Cell and Bacterial Counts. J Dairy Sci. 2004; 87: 3561-3573.

Jones GM, Sumner S. Testing Bulk Tank Milk Samples Publication No.404-405, Virginia Coop. Ext., Virginia Tech, Blacksburg, 1999.

Koçyiğit R, Yılmaz O, Özenç E, Uçar M. Effect of some risk factors on subclinical mastitis in dairy cows. Kocatepe Vet J. 2016; 9(3): 185-193.

Köker A, Erdem H. Sağım ve Sağım Makinelerinin Temel İlkeleri. In: Evcil Hayvanlarda Meme Hastalıkları, Eds: Kaymaz M, Fındık M, Rişvanlı A, Köker A. Medipres Yayıncllk, Malatya.2016;s: 101-146.

Küplülü Ş, Vural R. Büyük Ruminantlarda Meme Sağlığı Kontrol Programları. In: Evcil Hayvanlarda Meme Hastalıkları. Eds: Kaymaz M, Fındık M, Rişvanlı A, Köker A. Medipres Yayıncllık, Malatya. 2016;s: 261-294.

Lam TJGM, Van den Borne BHP, Jansen J, Huijps K, Van Veersen JCL, Van Schark G, Hogeveen H. Improving bovine udder health: A national mastitis control program in the Netherlands. J Dairy Sci. 2013; 96: 1301-1311.

Marshall RT. Standard Methods for Examination of Dairy Products. 16th ed. Am Publ Health Assoc Inc., Washington, DC. 1992.

Murphy SC, Martin NH, Barbano DM, Wiedmann M. Influence of raw milk quality on processed dairy products: How do raw milk quality test results relate to product quality and yield? J Dairy Sci. 2016; 99:1012810149.

National Mastitis Council. Current Concepts of Bovine Mastitis. Natl Mastitis Council Inc., Madison, WI. 1996; pp: $40-41$.

Önal AR, Özder M. Trakya'da özel bir süt işleme tesisi tarafindan değerlendirilen çiğ sütlerin somatik hücre sayısı ve bazı bileşenlerinin tespiti. Tekirdağ Ziraat Fakültesi Dergisi. 2007; 4(2): 195-199.

Pantoja JCF, Reinemann DJ, Ruegg PL. Associations among milk quality indicators in raw bulk milk, J Dairy Sci. 2009; 92: 4978-4987.

Patır B, Can ÖP, Gürses M. Farklı illerden toplanan çiğ inek sütlerinde somatik hücre sayıları. F Ü Sağlık Bilimleri Veteriner Dergisi. 2010; 24(2): 87-91.

Petersson-Wolfe CS, Tholen AR, Currin J, Leslie KE. Practical methods for mastitis control. WCDS Adv Dairy Technol 2013; 25: 341-358.

Sharif A, Muhammad G. Mastitis control in dairy animals Pakistan Vet J. 2009; 29: 145-148.

TÜİK 2019. Türkiye İstatistik Kurumu (TÜiK). Erişim Adresi: http://www.tuik.gov.tr/ Erişim Tarihi: 17.05.2019.

Wustenberg M. Diagnosing Bulk Tank Milk Bacteria Counts. Tillamook Country Creamery Assoc, NMC Annual Meeting, 2009. Erişim Adresi: https://www.medvet.umontreal.ca/rcrmb/dynamiques/ PDF_AN/Diagnosis/DiagnosisBTMBacteriaCount.pdf.

Vural R, Ergün Y, Özenç E.Büyük Ruminantlarda Mastitis. In: Evcil Hayvanlarda Meme Hastalıkları. Eds: Kaymaz M, Fındık M, Rişvanlı A, Köker A. Medipres Matbaacılık. 2016; s:149-259.

Zucalli M, Bava L, Tamburini A, Brasca M, Vanoni L, Sandrucci A. Effects of season, milking routine and cow cleanliness on bacterial and somatic cell counts of bulk tank milk, J Dairy Res. 2011; 78: 436-441. 